\title{
Verification of the Implementation of Land Cover Technology with Plastic Mulch for Control of White Grubs Lepidiota stigma Fabricius in Sugarcane
}

\author{
Dwi Adi Sunarto ${ }^{1 *}$, Subiyakto ${ }^{1}$ \\ ${ }^{1}$ Indonesian Sweeteners and Fiber Crops Research Institute, Malang 65152, Indonesia \\ *Corresponding Author. Email:dwiadizunarto@gmail.com
}

\begin{abstract}
Plastic mulch is one of the cultural practices that can be applied to control white grubs Lepidiota stigma Fabricius (Coleoptera: Scarabaeidae) in sugarcane. The strategy needs to be tested for its effectiveness in the broader area before it is disseminated to farmers or other users. This study aims to verify the pest control strategy of plastic mulch to control white grubs L. stigma in areas smallholder sugarcane farms. The study was conducted in Banyuputih Sub-district, Situbondo Regency, East Java, from November 2016 to December 2017. The total area used for this study was 4 ha. The treatments were $100 \%$ plastic mulch closure compared with no plastic mulch closure. Installation of plastic mulch is carried out the day after rain $(>4 \mathrm{~mm})$. The experimental design used an unpaired t-test with ten replications for each treatment. The results showed that the application of $100 \%$ plastic mulch closure was able to suppress the white grubs population and plant damage. The number of sugarcane population that can be saved from the damage by white grubs were $28 \%$. Plastic mulch practice caused an additional cost of 53\%, but this generated additional revenue of $69 \%$. Therefore, the technology of land cover with plastic mulch is feasible in the cultivation of sugarcane farming because it has a $\mathrm{B} / \mathrm{C}$ ratio of more than 1 and higher than sugarcane without using plastic mulch.
\end{abstract}

Keywords: sugarcane, white grubs control, Lepidiota stigma, plastic mulch

\section{INTRODUCTION}

White grub attacks sugarcane roots and endemic in some dry soil with light soil texture. The white grub attacks in Indonesia spread in East Java, Central Java, West Java, Yogyakarta, West Nusa Tenggara, and South Sumatera [13]. The white grubs species that dominantly causes damage to sugarcane in Indonesia is Lepidiota stigma Fabricius. It caused more than $50 \%$ damage against sugarcane and in severe attacks, it causing crop failure [4-7]. Therefore, white grubs control draws serious attention from farmers and researchers.

Damage caused by white grubs is visible and can be distinguished from the attacks of other pests on sugarcane. White grub attacks on newly planted crops cause plant death. If the attacked plants less than five months old, it leads to stunting sugarcane growth, and if it attacks plants more than five months old, then the plants will collapse easily. The control of white grubs pests in sugarcane has been done in various ways, including biological control [812], chemical control [13-15]; and cultural control [16]. All the control methods have not produced tangible results, especially in endemic areas. The white grub pest research in 2014 showed that the white grub population in Situbondo District was very high, reaching an average of 19.6 larvae per $\mathrm{m}^{2}$. The pest control strategies that have been applied in the field consisted of botanical pesticides, biopesticides, soil insecticides, and sugarcane intercropping with sesame still failed to provide optimal results since the average damage rate still more than $50 \%$ [6].

Mulch is a pest control technology that relatively expensive and has never been applied to sugarcane. Plastic film mulching is regularly applied to horticultural crops that have high economic value. Small scale research indicated that the best way to install plastic mulch in the field is immediate installation after the rain [17] and the soil surface completely covered [18]. However, the technology needs to be tested on a broader scale to determine the consistency of its effectiveness in controlling white grub pests. This study aims to evaluate the effectiveness of land cover technology using plastic mulch for controlling the white grubs L. stigma in sugarcane farms.

\subsection{Materials and Methods}

This study is a collaboration with farmers of Banyuputih Village, Banyuputih District, Situbondo Regency, East Java, Indonesia, which was conducted in white grubs endemic area from October 2016 to December 2017. The sugarcane plant used was RC-1 of Bululawang (BL) variety in a 4 ha land. We used $400 \mathrm{~kg}$ of NPK 15:15:15 fertilizer $+600 \mathrm{~kg}$ ZA per ha, with one-third of the dosage was applied in the first month after stem cutting, and the remaining dosage was administered three months after stem cutting. 
There were two treatments, i.e., with and without plastic mulch. Each treatment had 10 sample plots as replications the whole plots for each treatment consisting of a 2 ha area. The observed variables consisted of larval and beetles populations, crop damage, rainfall, production costs, and income of sugarcane cultivation. Lepidiota stigma population and the attack percentage was examined using a method developed by PT Gunung Madu Plantation (PT GMP) and Harjaka [5] with slight modifications in excavation length and width (Figure 1). White grub larvae population and plant damage samplings were carried out in each plot with five sample units. From each sample, five sample derivatives were taken, and each sample derivatives consisted of several cluster samples (5 meters/rows) with a minimum distance of 10 lines from the edge (Figure 1). The white grub larvae populations were observed by digging the soil on the side of sugarcane. The size of the soil extraction was $2 \mathrm{~m} \times 0.5 \mathrm{~m} \times 0.5 \mathrm{~m}$ (length, width, and depth). Observations were made by opening the plastic mulch and covering it again right after the observations completed. These observations were carried out every 7-day of intervals from 23 November 2016 to 16 August 2017. From March to August 2017 crop damage assessment was carried out with the intervals of 1-2 months between the observations. The white grub beetles were observed through installing a light trap from 7 October 2016 to 31 March 2017 at 7-day intervals. Sugar factories provided data on sugarcane production, yield, crystal, and molasses. The farming analysis of cost and profit was done by calculating production costs, revenues, and income.

Data were analyzed using a t-test, with 10 replications. Benefit-Cost (B/C) Ratio analysis was used as a decision criterion to measure the profit level of new technologies in the farm production process. $\mathrm{B} / \mathrm{C}>1$ means that the plastic mulch technology provides extra benefits higher than the cost. $\mathrm{B} / \mathrm{C}<1$ means the technology application provides extra costs higher than the benefits. And, $\mathrm{B} / \mathrm{C}=1$ means the extra benefits of applying plastic mulch equal with extra costs Malian [19].

\subsection{Our Contribution}

The application of the use of plastic mulch has never been done on sugarcane and is a relatively expensive pest control method, so this method must be ensured to be effective and efficient. The technology is needed for sugar cane endemic pests. In endemic areas, uret pest can cause more than $50 \%$ crop damage and can even cause crop failure. In these conditions there is no technology that can control it, so that plastic mulch technology is an option even though it is expensive.

\subsection{Paper Structure}

The structure of this paper is organized as follows. Section 1 is an introduction that explains the importance of L. stigma insects, some ways of controlling them, and the purpose of the study. Section 2 is the research methodology that informs the implementation time, the area of the study, the maintenance of sugarcane, the treatment in the study, the observation variables, the way of observation, and the analysis of the data used, and discussion explaining uret infestation, damage to sugarcane, productivity of sugarcane, and farming analysis.

\section{RESULTS AND DISCUSSION}

Timeliness of plastic mulch installation is crucial for the effective utilization of land cover technology in controlling white grubs. Rainfall is the criterion used as the basis for installing plastic mulch. Installation of plastic mulch is recommended as soon as it rains > $4 \mathrm{~mm}$ [17]. The 2016 rainfall in Asembagus was an anomaly, where rain occurred almost throughout the year, and the rain stopped only in August 2016 (Figure 2), making it difficult to determine the right time to install the plastic mulch. Aside from this, the
Sample 1

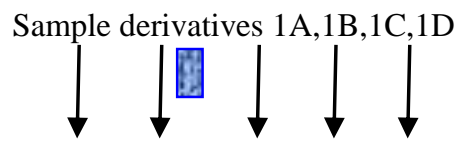

Sample 3

Sample derivatives 3A,3B,3C,3D
Sample 5

\section{Sample 2}

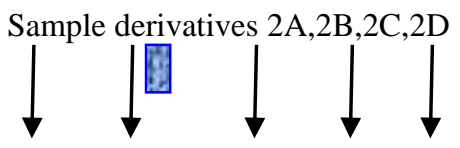

Sample derivatives 5A,5B,5C,5D

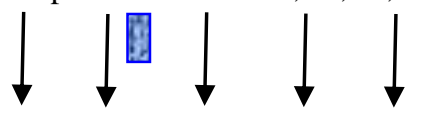

Sample 4

Sample derivatives $4 \mathrm{~A}, 4 \mathrm{~B}, 4 \mathrm{C}, 4 \mathrm{D}$

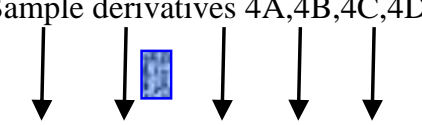

$=$ Observation box of white grubs larvae population length $\mathrm{x}$ width $\mathrm{x}$ inside $=2 \mathrm{~m} \times 0.5 \mathrm{~m} \times 0.5 \mathrm{~m}$

Figure 1 Sampling method for observing white grubs larvae 


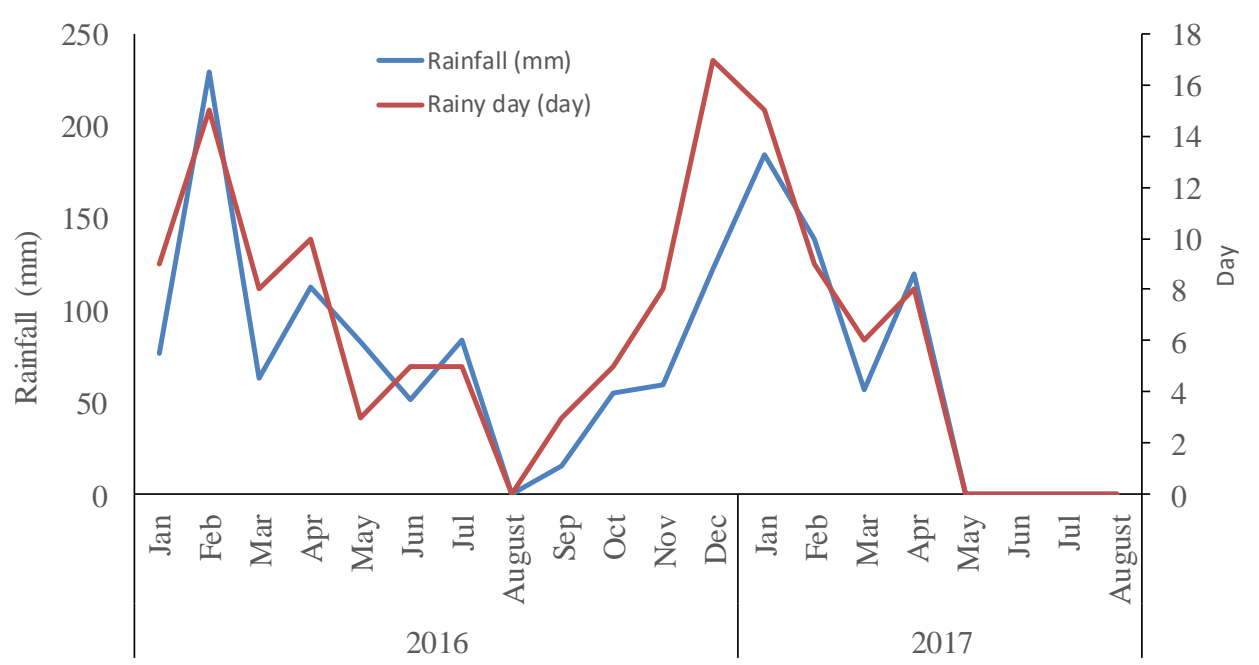

Figure 2 Rainfall during the period of 2016-2017 in Asembagus, Situbondo

sugarcane cutting period in the research location was completed in October - November 2016. Thus, the installation of plastic mulch can only be carried out in December 2016. These conditions were challenges that tested the effectiveness of the plastic mulch technology in controlling white grubs. Subiyakto and Sunarto [17] stated that the installations of plastic mulch at $1,7,14$, and 21 days after rain (DAR) had a significant effect on the white grub population compared to without mulch. In that case, the installation of plastic mulch more than 21 DAR may still have the chance to controlling white grubs.

Rainfall becomes the base for the appropriate time to install plastic mulch because rainfall influences the flight time of the white grub beetles. The final instar of white grubs that lives in the soil will be encouraged to become pupae, imago stage and then fly to copulate, usually occurring 2-3 months after the rain. When the beetles start flying, it can be monitored using light traps (Figure 3 ). The flight season of white grub beetles in Indonesia usually occurs in November-December [20]. For that reason, there were no beetles were found during four observations in October. Adults begin to emerge in early November 2016 to the end of February 2017. They are most abundant in December 2016, with the highest in the second week of December, where 83 beetles observed. Furthermore, the population declined until there were no flights in the first week of March 2017. The plastic mulch installation should be installed based on the time beetle's flight period started. In this case, it should be in November 2016. However, in this study, the mulch was installed after the peak of the beetle population.

White grub larvae infestations in the field usually occur 2-3 months after beetle flight [20]. Larvae populations in this study were found at the beginning of the observation period in November (Figure 4). It shows that the rainfall throughout 2016 affected the presence of white grub larvae, which were found earlier than usual. The studies in 2014 and 2015 by Subiyakto and Sunarto [17] and Sunarto and Subiyakto [18] reported that white grub larvae infestation was not shown until in January. The larval stages in the three initial observation periods prior to the closure treatment of the plastic mulch varied from first to fourth instars [21]. The observed larval size indicates that beetles' infestations occurred before November 2016 or earlier than average conditions. Meanwhile, the beetle larvae were detected early in November 2016, and this might be the reason why the light traps cannot function effectively since the adult population is low. Plastic mulch installation seems to be able to suppress the white grub larvae populations. The larvae populations before the plots covered with plastic mulch showed unevenness between the experimental plots (Figure 4). From three initial observations in plastic mulch plots, we collected 1.33 larvae $/ \mathrm{m}^{2}$ averagely, while in the plot without mulch, it was $0.33 \mathrm{larvae} / \mathrm{m}^{2}$. However, on eight observations or 52 days after treatment, the effect of plastic mulch began to appear. Larvae populations in the plots without mulch in the observation period February to August 2017 increased and was higher than in the plastic mulch plots with an average population of 1.99 larvae $/ \mathrm{m}^{2}$ and 0.96 larvae $/ \mathrm{m}^{2}$, respectively. Plastic mulch caused a decrease in larval beetle populations because it interfered with beetle oviposition [17]. Additionally, it is suspected that the natural mortality factor also contributed to lower populations in the plastic mulch plots.

The symptoms of attacked plants began to show after 56 months, which was in May 2017, where the damage was $18 \%$ for plots without mulch and $1 \%$ in plots using plastic mulch. At the end of the observation period, damaged plants increased in plots without mulch up to $30 \%$ and plots using plastic mulch by $2 \%$ (Table 1 ). The percentage of damaged plants in plots without mulch was lower compared to 2014 and 2015 studies, which more than 50\% [6, 17, 18]. However, this level of damage in this study is still beyond the economic threshold for controlling white grubs using 
by farmers in the form of sugar and molasses. With a sugar cane content of $8.59 \%$, the results obtained as much as 9.07 $\mathrm{kg}$ of sugar and molases of $3.17 \mathrm{~kg}$ per ha in the plastic mulch closure treatment were significantly different from those without mulch (Table 2). These results indicate that land cover technology using plastic mulch consistently provided favorable results when it was applied to the area with economics scale that meet sugarcane farming.

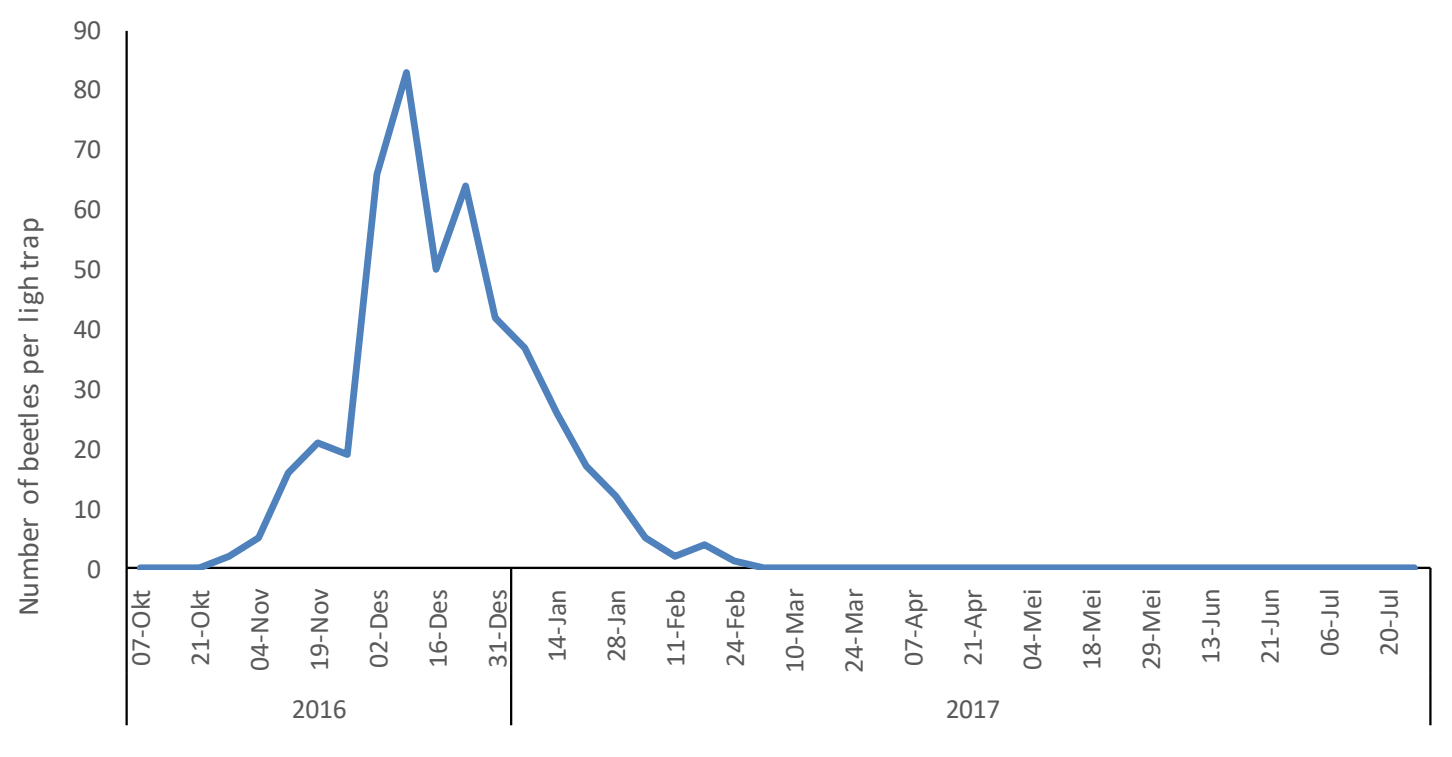

Date of observation

Figure 3 Lepidiota stigma beetle caught by a light trap

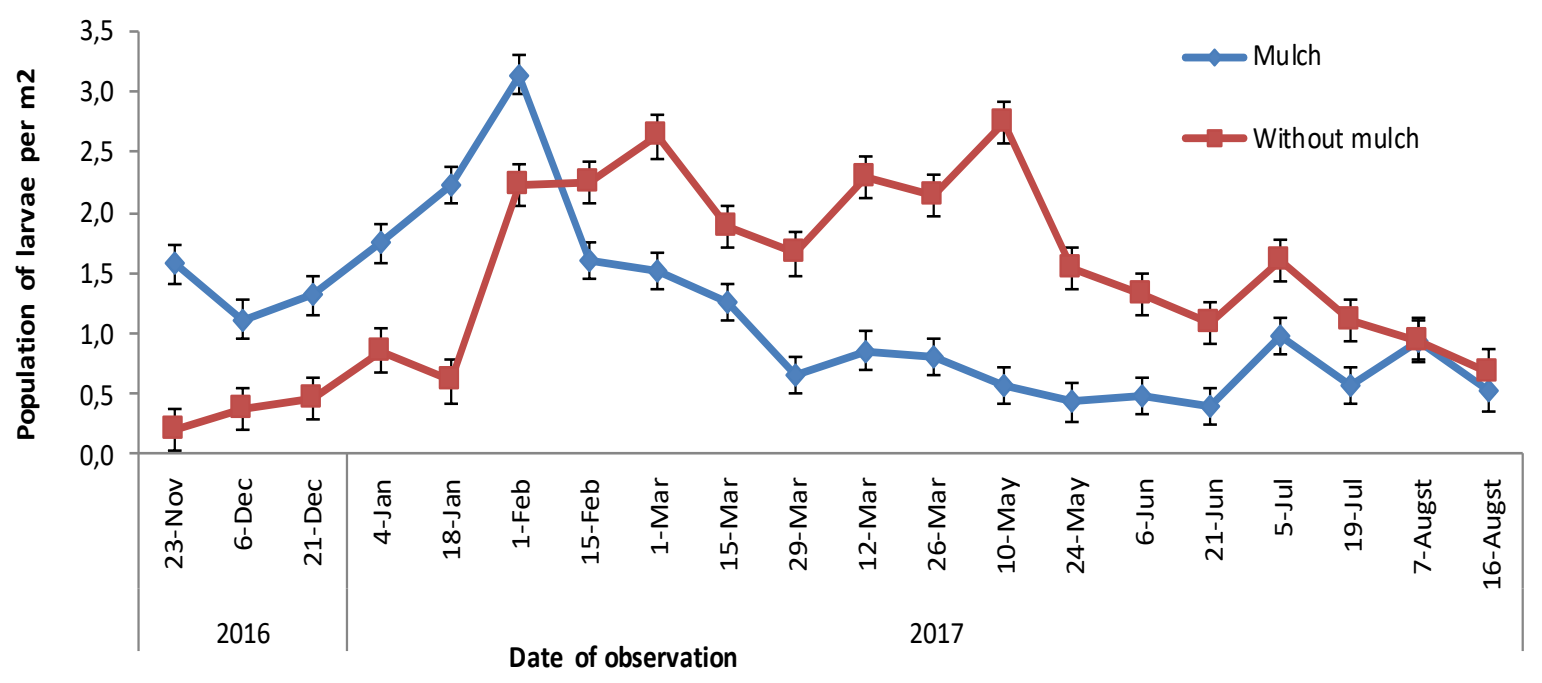

Figure 4 Average population of white grubs $\left(\right.$ larvae $\left./ \mathrm{m}^{2}\right)$ in the treatments of plastic mulchand without mulch 
Table 1 Percentage of crop damage by white grubs in plots treated with plastic mulch and without mulch

\begin{tabular}{|l|c|c|c|c|}
\hline \multirow{2}{*}{ Treatment } & \multicolumn{4}{|c|}{ Crop damage (\%) } \\
\cline { 2 - 5 } & March 3, 2017 & May 5, 2017 & July 4, 2017 & August 3, 2017 \\
\hline Plastic mulch & 0 & 1 & 2 & 2 \\
\hline Without mulch & 0 & 18 & 30 & 30 \\
\hline
\end{tabular}

Table 2 Production of sugarcane, sugar, and molasses in plots treated with plastic mulch and without mulch.

\begin{tabular}{|l|c|c|c|}
\hline \multirow{2}{*}{ Treatment } & \multicolumn{3}{|c|}{ Production $(\mathbf{k g} / \mathbf{h a})^{*}$} \\
\cline { 2 - 4 } & Sugarcane & Sugar & Molasse \\
\hline Plastic mulch & $105.62 \mathrm{a}$ & $9.07 \mathrm{a}$ & $4.52 \mathrm{a}$ \\
\hline Without mulch & $69.72 \mathrm{~b}$ & $5.99 \mathrm{~b}$ & $2.99 \mathrm{~b}$ \\
\hline
\end{tabular}

Note: $8.59 \%$ sugar yield

* Production percentage followed by different letters in the same column are significantly different at $5 \%$

Table 3 Farmer income from sugarcane farming in the treatment using plastic mulch and without mulch

\begin{tabular}{|l|c|c|c|c|c|}
\hline \multirow{2}{*}{ Treatment } & \multicolumn{2}{|c|}{$\begin{array}{c}\text { Product allocation for farmers } \\
(\mathbf{k g})\end{array}$} & \multicolumn{2}{c|}{ Price (IDR) } & \multirow{2}{*}{ Income (IDR) } \\
\cline { 2 - 5 } & Sugar & Molasses & Sugar & Molasses & \\
\hline Plastic mulch & 5.90 & 3.17 & 9,700 & 1,200 & $61,053,400$ \\
\hline Without mulch & 3.36 & 2,09 & 9,700 & 1,200 & $35,123,000$ \\
\hline
\end{tabular}

Note: The allocation of sugar products received by farmers is $70 \%$ of the total sugar produced (crystal)

Applying this technology to the sugarcane field resulted in an additional income of $69 \%$, even though it required an extra cost of 53\%. Tables 3 and 4 show the cost and benefit of sugarcane cultivation with and without mulch. There was a significant difference in the implementation cost of plastic mulch on the sugarcane field. Cost differences occur due to the purchase of mulch, landfill, installation, and dismantling the plastic mulch. Weed growth in plastic mulch plots was relatively low, so that the weeding was easier, and this can be done together with landfilling. However, the cost of the landfill in plastic mulch plots was higher than without mulch because they had to uncover the plastic mulch before landfilling.

The total cost of sugarcane cultivation by applying plastic mulch reached IDR 36,143 million per ha, and the plot without mulch was only IDR 22,949 million per ha, resulting in an additional cost of IDR 13,194,236 per ha. The income received from sugar and drops production amounted to IDR $61,053,000$ for plastic mulch areas and IDR 35,123,000 for non-mulch. The sugarcane farms income with plastic mulch were IDR $61,053,000$ for 5,902 $\mathrm{kg}$ sugar and $3,170 \mathrm{~kg}$ molasses per ha whereas, for treatment without mulch, the income was IDR 35,123,000 for $3.36 \mathrm{~kg}$ sugar and $2.09 \mathrm{~kg}$ molasses per ha. The surplus from the application of plastic mulch technology is IDR
$25,930,400$. Based on the calculation of the extra revenues and costs, a $\mathrm{B} / \mathrm{C}$ ratio of 1.97 is obtained, which shows that the application of land cover technology using plastic mulch is more profitable than without mulch. Thus, using plastic mulch to control white grubs was proven to be more productive and economically beneficial than without using plastic mulch.

This study showed that plastic mulch increases sugarcane productivity and effectively controlling white grubs in field trials in smallholder sugarcane farms. The use of plastic mulch requires an expensive investment, but this technology is quite efficient for white grub control in endemic areas. Besides, the use of mulch has the potential to reduce groundwater evaporation and control weeds. Therefore it is highly recommended to apply this technology in white grubs endemic areas, which are generally dry land with sandy soil structure. Plastic mulch is a new technology for controlling white grubs in sugarcane and the outcomes of this study showed that this technology is ready to be introduced in other endemic areas such as in Kediri, Lamongan, Tulungagung, Lumajang, Jember, Bondowoso, Purworejo, and Sleman. 
Table 4 Farming analysis on land cover treatment using plastic mulch and without mulch

\begin{tabular}{|c|c|c|}
\hline \multirow{2}{*}{ Cost and income description } & \multicolumn{2}{|c|}{ Cost (IDR/ha) } \\
\hline & Plastic mulch & Without mulch \\
\hline \multicolumn{3}{|l|}{ Cost } \\
\hline Cutting ratoon sugarcane & $2,500,000$ & $2,500,000$ \\
\hline Replanting dead seeds & 500,000 & 500,000 \\
\hline Fertilizing 2 times & 800,000 & 800,000 \\
\hline Landfilling 2 times & $2,110,000$ & \\
\hline Weeding \& landfilling 2 times & & $1,610,000$ \\
\hline Clean the dried leaves 2 times & $2,500,000$ & $2,500,000$ \\
\hline Installing plastic mulch & $1,500,000$ & - \\
\hline Dismantling plastic mulch & 810,000 & - \\
\hline Harvest, loading and transporting & $15,843,450$ & $10,459,214$ \\
\hline Fertilizer (NPK+ZA) & $4,580,000$ & $4,580,000$ \\
\hline $\begin{array}{l}\text { Plastic mulch can be used for } 2 \text { seasons (1 season @ } \\
\text { IDR 5,000,000) }\end{array}$ & $5,000,000$ & - \\
\hline Total cost & $36,143,450$ & $22,949,214$ \\
\hline Additional cost & $13,194,236$ & - \\
\hline \multicolumn{3}{|l|}{ Income } \\
\hline Income (sugar + molasses) & $61,053,400$ & $35,123,000$ \\
\hline Additional income & $25,930,400$ & - \\
\hline B/C Ratio & 1.97 & - \\
\hline
\end{tabular}

\section{CONCLUSION}

The results of this study established that plastic mulch had suppressed the white grub populations and plant damage. Sugarcane damage in plastic mulch plots is lower than without mulch, with a difference of $28 \%$. The application of plastic mulch causes an additional cost of $53 \%$ but generates an extra income of $69 \%$. Land cover technology using plastic mulch is profitable to be applied in sugarcane cultivation because it has a $\mathrm{B} / \mathrm{C}$ ratio of 1.9 .

\section{ACKNOWLEDGMENT}

The author thanks Syamsul Arifin as a field technician and Suhadi SP. as head of the Asembagus Experimental Garden which has facilitated research. We also thank the leaders of the Indonesian Sweeteners and Fiber Crops Research Institute who have funded this research.

\section{REFERENCES}

[1] C. Daniati, Petani tebu kediri ramai-ramai kendalikan uret. Kementerian Pertanian. Direktorat Jendral

Perkebunan file://F/makalah/referensi/tebu/Kementeria Pertanian-Direktorat Jenderal PerkebunanPerlindungan Tanaman.html, 2018.

[2] A. Fauzi, Serangan hama uret di perkebunan tebu jengkol kabupaten kediri. Dep. Proteksi, Fak. Pertanian, Inst. Pertan. Bogor, 2015, 15p

[3] E. Setyaningsih, Lepidiota stigma menyerang tanaman tebu di kecamatan kedungwaru. BPP Kedungwaru, Tulungagung, 2012.

[4] T. Harjaka, Pengembangan patogen serangga untuk pengendalian uret perusak akar tebu. Disampaikan 
grubs and their effects on the yield of sugarcane in Bangladesh. PSJ. 24 (1) (2009) 2-5

2014, 2014

[5] M. Lutfi, S. Melina, Uret Lepidiota stigma Bisa Mengancam Sembada Gula Nasional 2014, BP2TP Surabaya, 2011.

[6] Subiyakto, Pengendalian Hama dan Penyakit Penting pada Tanaman Tebu. Laporan Hasil Penelitian Balittas Tahun Anggaran 2014, 2014.

[7] Subiyakto, Pengendalian Hama dan Penyakit Penting pada Tanaman Tebu. Laporan Hasil Penelitian Balittas Tahun Anggaran 2015, 2015.

[8] C. Chelvi, W.R. Thilagaraj, R. Nalini, Field efficacy of formulations of microbial insecticide Metarhizium anisopliae (Hyphocreales: Clavicipitaceae) for the control of sugarcane white grubs Holotrichia serrata F. (Coleoptera :Scarabidae). J Biopesticides. 4(2) (2011) 186-189

[9] S. Manisegaran, S.M. Laksmi, V. Srimohanapriya, Field evaluation of Metarhizium anisopliae (Metschnikoff) Sorokin against Holotrichia serrata (Blanch) in sugarcane, J Biopesticides. 4 (2) (2011) 190-193

[10] B. Rathour, P.B. Mohite, R.B. Gite, Bioefficacy of entomopathogenic nematode, Heterorhabditis indica against white grubs, Phyllognathus dionysius Feb. under laboratory condition. J Global Biosciences. 4 (12) (2015) 1278-1282

[11] C. Sankaranarayanan, N. Somasekhar, B. Singaravelu, Biocontrol potential of entomopathogenic nematodes heterorhabditis and steinernema against pupae and adults of white grubs Holotrichia serrata F. Sugar Tech. 8 (4) 268271

[12] M. Pawirosemadi, Dasar-dasar teknologi budidaya tebu dan pengolahan hasilnya., 1st ed. ed. Universitas Negeri Malang, Malang, 2011, 812p

[13] M.H. Miah, M. Biswas, A. Mannan, Effects of some insecticides on white grubs control and yield of sugarcane. J Trop Pest Manage. 32(4) (2008) 338340

[14] O. Rahama, M. Abdallaa, A, M. El Naim, Control of White Grubs Adoretus emarginatus Ohaus and Heteronychus licas Klug (Coleoptera: Scarabaeidae) in Sugarcane. WJAR [online]. 2 (4) (2014) 155-158. https://doi.org/10.1269 1/wjar-24-3

[15] M.N.A Siddique, M. Abdullah, M.A. Alam, M. Rahman, Effects of some new organocarbamate \& organophosphate insecticides in controlling white
[16] R.H. Cherry, Correlation of crop age with populations of soil insect pests in Florida sugarcane. J Agric Entomol. 5 (1988) 241-245

[17] Subiyakto, D.A. Sunarto, Periode penutupan tanah dengan mulsa plastik terhadap populasi uret (Lepidiota stigma Fabricius) dan produktivitas tebu. J Littri. 24 (1) (2018) 21-28. DOI: http://doi.org/10.21082/littri.v24n1. 2018

[18] Sunarto, D.A. dan Subiyakto. Efisiensi penggunaan mulsa plastik dalam pengendalian uret (Lepidiota stigma Fabricius) pada Tanaman Tebu. Buletin Tanaman Tembakau, Serat \& Minyak Industri. 10(2) (2018) 55-63. DOI: https://doi.org/10.21082/btsm.v10n2.2018 .55-63

[19] Malian, A. Husni, Analisis ekonomi usahatani dan kelayakan finansial teknologi pada skala pengkajian. Pusat Penelitian dan Pengembangan Sosial Ekonomi Pertanian dan Proyek Pengkajian Teknologi Pertanian Partisipatif (The Participating Development of technology Transfer Project (PAATP). Badan Penelitian dan Pengembangan Pertanian, 2004.

[20] E.M. Achadian, A. Kristiani, R.C. Magarey, N. Sallam, P. Samson, F.R. Goebel, K. Lonie, Hama dan penyakit tebu, Buku Saku, Kerjasama P3GI dengan BSES Limited, Australia dan ACIAR, 2011, $154 \mathrm{p}$

[21] D. Pramono, Sugarcane uret in Indonesia. Paper contributed for crop compedium. C.A.B International, London, 1995, 21p 